Available online at

http://ojs.unik-kediri.ac.id/index.php/ukarst/index

\title{
Performance Assessment of Bondoyudo Watershed Management
}

\author{
H. B. Sulaksono ${ }^{1}$, G. Halik ${ }^{2 *}$, R. U. A. Wiyono ${ }^{3}$. \\ 1,2*3 Master Program in Civil Engineering, Department of Civil Engineering, Faculty of Engineering, \\ University of Jember. \\ Email:2*gusfan.teknik@unej.ac.id
}

\begin{tabular}{ll} 
A R T I C L E I N F O \\
\hline ArticleHistory : \\
Article entry & $: 26-12-2020$ \\
Article revised & $: 12-01-2021$ \\
Article received & $: 05-02-2021$ \\
\hline
\end{tabular}

Keywords :

Bondoyudo, Carrying Capacity, Criteria, Performance Watershed.

IEEE Style in citing this article : [1] J. Mosaffaie, A. Salehpour Jam, M. R. Tabatabaei, and M. R. Kousari, "Trend assessment of the watershed health based on DPSIR framework," Land use policy, vol. 100, no. October 2019, 2021, doi: 10.1016/j.landusepol.2020.10491 1.

\section{Introduction}

The uncontrolled impact of land use in the Bondoyudo watershed without paying attention to soil and water conservation principles has resulted in high erosion and sedimentation rates. Decreasing vegetation cover in the upstream Bondoyudo watershed accelerates land degradation. These changes lead to an increase in critical land area, decrease in quantity, quality, and continuity of flow, even prone to flood and drought risks so that socioeconomically causes people to lose their ability to run their land as a efforts to improve the general welfare. There have been many studies on watershed assessment in other areas [1][4].

PerformanceAssessment of Bondoyudo Watershed Management 
The increase in population in the Bondoyudo watershed and the development of agribusiness, agriculture, and industry have pushed policies that have not synergized with the new regulations.. The conversion of land and planting functions along the river and upstream of the Bondoyudo watershed has contributed to the disruption of the current decade's natural balance.

This study focused on monitoring and evaluating the Bondoyudo watershed's management to find out information on the performance of the Bondoyudo watershed. It is necessary to formulate the following matters the current condition of the Bondoyudo watershed, the availability of water in the watershed area of the Bondoyudo River, starting in the upstream, middle to the river mouth. The performance management of the Bondoyudo watershed in developing sustainable water resources in the future is also discussed in this study.

Performance conditions of the Bondoyudo watershed according to the assessment parameters from weighted criteria were evaluated. Various conditions, including land conditions, river, and hydrological conditions, socio-economic and institutional conditions, were considered [5]. Conditions of area designation, asset conditions, and water construction investment were monitored so that the watershed carrying capacity takes place effectively, efficiently, and sustainable. The aspects of quantity, quality, and continuity are the basis for developing sustainable water resources in the future.

\section{Literature Review}

\subsection{Land Analysis Criteria}

\subsubsection{Sub Critical Land Criteria}

Critical land is a land inside and outside the forest area that has decreased its function as an element of production and a medium for regulating watershed water management [6]. Critical land monitoring is conducted to determine the percentage of critical land area in the watershed. The calculation of the percentage of critical land area uses the classification as given by Minister of Forestry Regulation 2014 [7], as follows

Percentage Critical Land $(P C L)=\frac{\text { critical land area }}{\text { watershed area }}$

\subsubsection{Vegetation Cover Criteria}

Monitoring and evaluation of vegetation cover are carried out to determine the 
The percentage of land area with permanent vegetation cover in the watershed, which is the ratio of the area of permanent vegetation to the watershed area. The calculation of the percentage area of vegetation, as follows

Percentage Cover Vegetation $(P C V)=\frac{\text { cover vegetation area }}{\text { watershed }} x 100 \%$

\subsubsection{Erosivity Index Sub Criteria}

Land monitoring related to erosion is approximate by the erosion index value in the watershed, which is the ratio of actual erosion to permissible erosion [8]. The actual erosion data is obtained from erosion calculations using the Universal Soil Loss Equation (USLE) method.
$\mathrm{A}=$ R. K. LS. C. P
Discription :
$\mathrm{R}=$ Rain Erosivity Factor[9]
$\mathrm{K}=$ Soil Erodibility Factor [10]
LS = Length and Slope Factor
$\mathrm{C}=$ Land Cover Factor
$\mathrm{P}=$ Land Management Factor

\subsection{Water System Criteria}

\subsubsection{Flow Regime Coefficient Sub Criteria}

The factors influencing river discharge are rainfall, topographical, geology, vegetation, and human conditions [11]. The calculation of the flow regime coefficient, as follows

Flow Regime Coefficient $(F R C)=\frac{\mathrm{Qmax}}{\mathrm{Qmin}}$

Description: Qmax is a maximum discharge; Qmin is a minimum discharge;

\subsubsection{Annual Flow Coefficient Sub Criteria}

The analysis of annual flow coefficient calculations obtained from the calculation of rainfall data and river discharge. The calculation of the annual flow coefficient, as follows Annual Flow Coefficient $(A F C)=\frac{\mathrm{Q}}{\mathrm{P}}$

Description: $\mathrm{Q}$ is an annual discharge; $\mathrm{P}$ is an annual rainfall; 


\subsubsection{Water Use Index Sub Criteria}

In this analysis, the water use index calculation uses a comparison between water demand and water availability in the watershed. The calculation of the annual flow coefficient, as follows

Water Use index $(W U I)=\frac{\text { Water Demand }}{\text { Water Availability }}$

\subsection{Socio - Economic Criteria}

\subsubsection{Population Pressure Analysis}

The land availability index's population pressure analysis compares agricultural land and the number of farmer families in the watershed. The population pressure index for the land calculates using the formula.

Population Pressure Analysis $(P P A)=\frac{\mathrm{A}}{\mathrm{P}}$

Description: $\mathrm{A}$ is an area of agricultural land; $\mathrm{P}$ is a number of farmer families

\subsubsection{Population Welfare Analysis}

The criteria for the level of population welfare are approached by a percentage of low-income families or the average per-capita income level per year [12]. The Population Welfare Index (PWA) for the land calculated using the formula.

Population Welfare Analysis $(P W A)=\frac{\text { Poor households }}{\text { Total households }} \times 100 \%$

\subsection{Space Utilization Criteria}

Protected areas are defined with the primary function of protecting the environment's preservation, including natural and human-made resources[13]. The characteristics of land with steep slopes and erosion-sensitive soil are areas that need protection [14]. The Protected Area Analysis (PAA) calculated using the formula.

$$
P A A=\frac{\text { vegetation coverage }}{\text { area of vegetation coverage in protected areas }} x 100 \%
$$

\section{Research Method}

The topographical condition of the Bondoyudo watershed in the upstream area has an extreme high difference so that the flow is quite heavy, in the middle, it varies with 
Lowlands, undulating plains, and highlands (hilly), covered with rice fields and hilly vegetation, tend to be transitional, while downstream areas tend to have shallow currents.

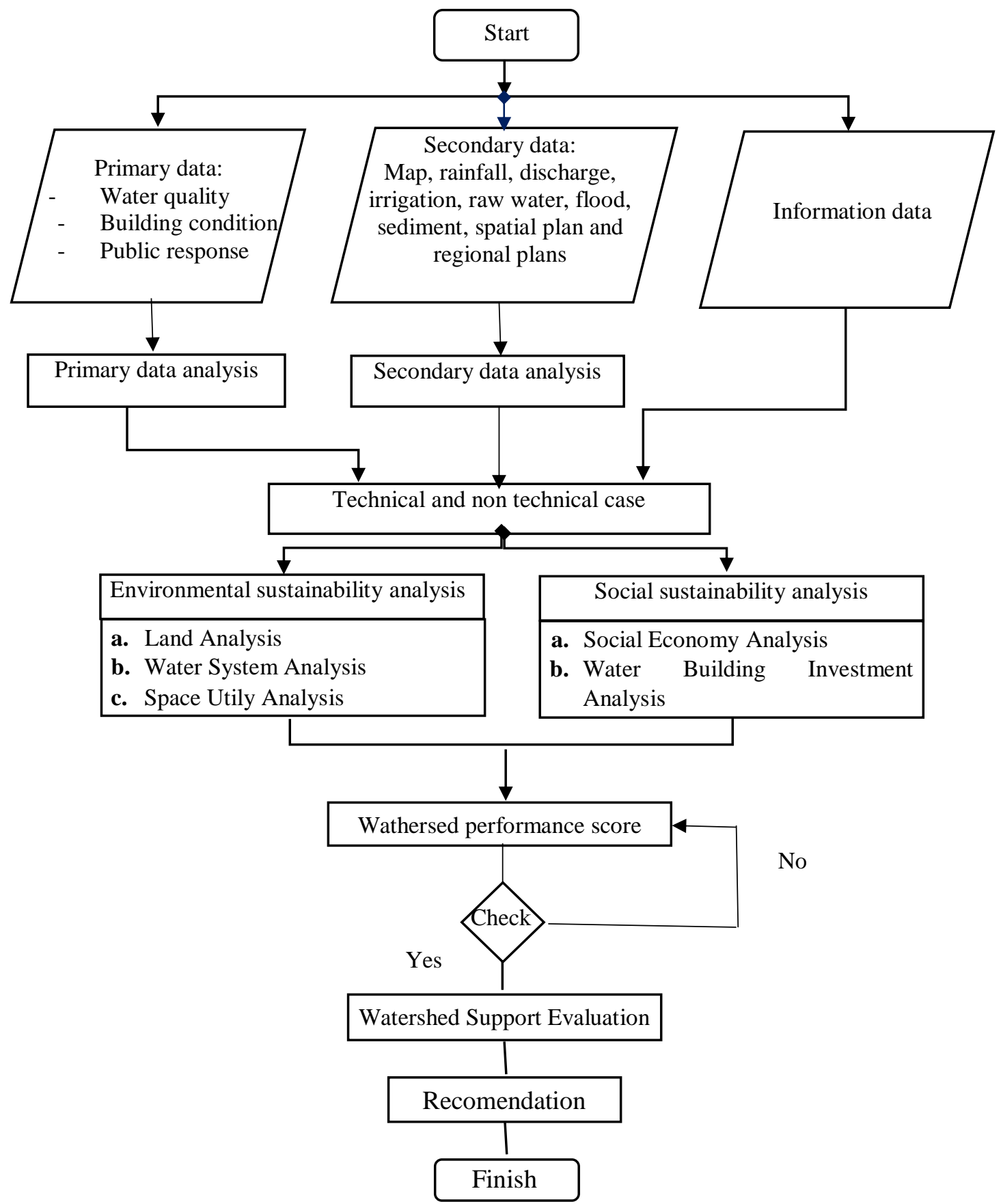

Figure 1. Research steps of Performance Assessment of Bondoyudo Watershed Management

The research steps are presented in Figure 1. The data collection process consists of primary data, secondary data, and other information. Primary data are water quality data, building condition data, and public response. In contrast, secondary data includes maps, rainfall, discharge data, irrigation data, raw water data, flood occurrence data, and sediment data. After data collection, 
conducted environmental and social sustainability analyses to obtain a watershed performance score. Watershed support evaluation and recommendation are discussed as the final step.

\section{Results and Discussions}

\subsection{Land Analysis Criteria}

\subsubsection{Critical Land Analysis}

The potential for critical land in the Bondoyudo-Bedadung watershed is classified into 5 types [15]. Determination of the classification of critical land was obtained by comparing the area of critical land to the total area of the Bondoyudo watershed. $\mathrm{PCl}=$ $\frac{44,62}{1345,2} \times 100 \%$. The obtained PCL value was 3.32 , belonging to the very low land recovery qualification class criteria.

\subsubsection{Vegetation Cover Analysis}

Based on the land use map of Lumajang, Jember, and Probolinggo districts, it is know that most of the Bondoyudo watershed is a production forest area and community forest area of 55,198 ha (41\%). Data on the area of land use in the Bondoyudo watershed is presented in Table 1

Table 1. Types of Land Cover in the Bondoyudo Watershed

\begin{tabular}{cccc}
\hline \multirow{2}{*}{ No. } & Land Cover & \multicolumn{2}{c}{ Area } \\
\cline { 2 - 4 } & & Ha & Percentage \\
\hline 1 & Protected Forest Area & $6.855,73$ & 5,10 \\
2 & National Parks & $11.681,20$ & 8,86 \\
3 & Production Forest Area & 11.960 & 8,89 \\
4 & Community Forest Area & $43.238,35$ & 32,14 \\
5 & Settlement & $11.963,26$ & 8,89 \\
6 & Agricultural land & $44.041,00$ & 32,74 \\
7 & Plantation land & 4,560 & 3,39 \\
8 & Fishery land & 95,53 & 0,07 \\
9 & Rivers and streams & 125,00 & 0,09 \\
Total & & 134.52 & 100 \\
\hline
\end{tabular}

Source: Author's analysis, 2020

From Table 1, it is obtained that the area of permanent vegetation is calculated of protected forest area, national parks, production forest area, and the community forest area is $78,295.29$ ha with a value of land cover presentation or PCV obtained at $58 \%$. The PCV value of $58 \%$ belongs to the medium recovery class vegetation cover. 


\subsubsection{Erosivity Index Analysis}

\section{A. Erosivity Index (R)}

The calculation of the rain erosivity factor was obtained from the monthly average rainfall data using the Thiessen polygon method based on 10 years of rainfall data from the PUSDA Office of East Java Province obtained from 6 rainfall stations in the Bondoyudo watershed [16]. Based on the calculations of rainfall erosivity for 10 years, the average total monthly rainfall in 10 years is calculated. The average of total monthly precipitation in 10 years is $1.577,121 \mathrm{~cm} /$ year.

B. Slope length and slope factor (LS)

Based on the data from the topographical map of the Bondoyudo watershed, the distance between the elevations is obtained. The values are used to calculate the LS value (Table 2).

Table 2. Calculation of LS values

\begin{tabular}{cccrrc}
\hline No. & Elevation & Interval $(\mathrm{m})$ & \multicolumn{1}{c}{$\mathrm{L}(\mathrm{m})$} & \multicolumn{1}{c}{ S } & Ls $(\mathbf{m})$ \\
\hline 1 & $2000-2500$ & 500 & $3,156.7715$ & $.84 \%$ & 0.2732679 \\
2 & $1500-2000$ & 500 & $6,800.58$ & $7.35 \%$ & 0.1478925 \\
3 & $1000-1500$ & 500 & $8,997.20$ & $5.56 \%$ & 0.1182217 \\
4 & $500-1000$ & 500 & $10,374.754$. & $82 \%$ & 0.1054875 \\
5 & $200-500$ & 300 & $14,579.742$. & $06 \%$ & 0.0393002 \\
6 & $100-200$ & 100 & $12,533.180$. & $80 \%$ & 0.0095274 \\
7 & $50-100$ & 50 & $7,139.35$ & $0.70 \%$ & 0.0056631 \\
8 & $0-50$ & 50 & $47,353.380$. & $11 \%$ & 0.0012465 \\
\hline
\end{tabular}

Source: Author's analysis 2020

Based on Table 2, the longest Ls value $(0.273 \mathrm{~m})$ was obtained at elevation 2000$2500 \mathrm{~m}$, while the shortest Ls value $(0.0012 \mathrm{~m})$ was obtained at elevation $0-50 \mathrm{~m}$. The higher the elevation, the higher the Ls value is obtained.

\section{Erodibility Index $(\mathrm{K})$}

Soil erodibility factor, in other words, soil erosion sensitivity factor, is defined as whether or not the soil is easily eroded[17]. In addition to the value of the slope length and slope factor (LS), other factors such as soil erodibility (K), land cover, and land management (CP) factors are also calculated per elevation interval. The soil erodibility factor depends on the type of soil in the location related to the amount of $\mathrm{K}$ value for each type of soil[18]. A recapitulation of the average $\mathrm{K}$ value of the watershed can be seen in Table 3 . 
Table 3. Calculation of the average value of soil erodibility

\begin{tabular}{|c|c|c|c|c|c|c|}
\hline No & Elevation & Type of soil & Area & $\mathrm{K}$ & Area x K & Average of $\mathrm{K}$ \\
\hline 1 & $2000-2500$ & Andosol and regosol & 3.80 & 0.4 & 1.5216 & 0.400 \\
\hline 2 & $1500-2000$ & Andosol and regosol & 26.51 & 0.4 & 0.0568 & 0.400 \\
\hline 3 & $1000-1500$ & Andosol and regosol & 47.39 & 0.4 & 0.0804 & 0.400 \\
\hline 4 & $500-1000$ & Andosol and regosol & 100.66 & 0.4 & 0.1264 & 0.400 \\
\hline \multirow[t]{6}{*}{5} & $200-500$ & Brown regosol soil & 30.77 & & 12.307 & 0.400 \\
\hline & & Andosol and regosol & 91.01 & & 36.403 & \\
\hline & & regosol gray brown & 10.75 & 0.4 & 4.2990 & \\
\hline & & Brown regosol soil & 13.79 & & 5.5164 & \\
\hline & & regosol gray brown & 10.04 & & 4.0172 & \\
\hline & & Alluvial Hydromof & 2.30 & 0.47 & 0.0164 & \\
\hline \multirow[t]{6}{*}{6} & $100-200$ & Brown regosol soil & 137.71 & & 0.1526 & 0.410 \\
\hline & & regosol gray brown & 46.96 & 0.4 & 0.0800 & \\
\hline & & regosol gray brown & 14.27 & & 0.0391 & \\
\hline & & Reddish brown lithosol & 69.21 & 0.43 & 0.1117 & \\
\hline & & $\begin{array}{c}\text { Mediterranean brown and } \\
\text { Hydromoph }\end{array}$ & 4.56 & 0.46 & 0.0240 & \\
\hline & & Alluvial lithosol & 2.48 & 0.47 & 0.0171 & \\
\hline \multirow[t]{4}{*}{7} & $50-100$ & regosol gray brown & 40,1 & 0,4 & 0.0729 & 0.414 \\
\hline & & Brown regosol soil & 73.27 & & 0.1045 & \\
\hline & & Reddish brown lithosol & 70.89 & 0.43 & 0.1134 & \\
\hline & & $\begin{array}{l}\text { Mediterranean brown and } \\
\text { lithosol }\end{array}$ & 11.32 & 0.46 & 0.0414 & \\
\hline \multirow[t]{11}{*}{8} & $0-50$ & Brown regosol soil & 96.11 & & 0.1230 & 0.417 \\
\hline & & Gray regosol soil & 111.87 & 0.4 & 0.13470 & \\
\hline & & regosol gray brown & 170.52 & & 0.17355 & \\
\hline & & Gray brown alluvial & 24.06 & 0.47 & 0.06716 & \\
\hline & & Alluvial Hydromof & 23.27 & 0.47 & 0.06582 & \\
\hline & & $\begin{array}{c}\text { Mediterranean brown and } \\
\text { lithosol }\end{array}$ & 84.80 & 0.46 & 0.13877 & \\
\hline & & $\begin{array}{l}\text { Mediterranean brown and } \\
\text { lithosol }\end{array}$ & 84.80 & 0.46 & 0.13877 & \\
\hline & & Reddish brown lithosol & 26.68 & 0.43 & 0.06309 & \\
\hline & & Brown regosol soil & 73.27 & & 0.10453 & \\
\hline & & Reddish brown lithosol & 70.89 & 0.43 & 0.11340 & \\
\hline & & $\begin{array}{l}\text { Mediterranean brown and } \\
\text { lithosol }\end{array}$ & 11.32 & 0.46 & 0.04145 & \\
\hline
\end{tabular}

Source: Author's analysis 2020

Based on Table 3 the highest average $\mathrm{K}$ value at elevation 0-50.

D. Land cover factor $(\mathrm{C})$ and tillage factor $(\mathrm{P})$

The value of the land cover factor (C) is influenced by plant density and maintenance. The level of erosion that occurs due to the effects of soil management and conservation $(\mathrm{P})$ activities varies, mainly depending on the slope area. 
Table 4. Calculation of the average $\mathrm{CP}$ value

\begin{tabular}{cccccc}
\hline Elevation & Land Use Type & Area & CP value & Area x CP & Average of CP \\
\hline $2000-2500$ & Forest & 3.81 & 0.03 & 0.1144 & 0.03 \\
$1500-2000$ & Forest & 26.56 & 0.03 & 0.0015 & 0.03 \\
$1000-1500$ & Forest & 47.48 & 0.03 & 0.0021 & 0.03 \\
$500-1000$ & Forest & 100.86 & 0.03 & 0.0034 & 0.03 \\
$200-500$ & Forest & 143.07 & 0.03 & 4.2921 & \\
& Settlement & 4.77 & 0.6 & 0.1431 & 0.05 \\
& Rice fields & 11.13 & 0.05 & 0.3338 & \\
$100-200$ & Forest & 234.36 & 0.03 & 0.0056 & \\
& Settlement & 13.79 & 0.6 & 0.0010 & 0.0575 \\
$50-100$ & Rice fields & 27.57 & 0.02 & 0.0015 & \\
& Forest & 114.98 & 0.03 & 0.0036 & \\
& Rice fields & 57.49 & 0.02 & 0.0024 & \multirow{2}{*}{0.0356} \\
& Settlement & 19.16 & 0.03 & 0.0012 & \\
& Plantation & 4.50 & 0.4 & 0.0196 & \\
& Forest & 195.43 & 0.03 & 0.0050 & \\
& Rice fields & 235.71 & 0.02 & 0.0056 & 0.0256 \\
& Settlement & 104.53 & 0.03 & 0.0034 & \\
\hline
\end{tabular}

Source : Author's analysis 2020

Based on Table 4, the highest average of $\mathrm{CP}$ value was obtained at elevation 100$200 \mathrm{~m}$, while the lowest average of $\mathrm{CP}$ value was obtained at elevation $0-50 \mathrm{~m}$ with the same land use (forest, settlement, and rice fields).

E. Calculation of the rate of erosion $(\mathrm{A})$

The erosion value is calculated with the USLE formula. The calculation of the amount of land erosion is presented in Table 5, calculated for each elevation interval.

Table 5. Calculation of Bondoyudo Watershed Erosion Rate (A)

\begin{tabular}{cccccc}
\hline Elevation & R & LS & K & CP & A \\
\hline $2000-2500$ & 1577.121 & 0.27 & 0.400 & 0.0300 & 5.172 \\
$1500-2000$ & 1577.121 & 0.15 & 0.400 & 0.0300 & 2.799 \\
$1000-1500$ & 1577.121 & 0.12 & 0.400 & 0.0300 & 2.237 \\
$500-1000$ & 1577.121 & 0.11 & 0.400 & 0.0300 & 1.996 \\
$200-500$ & 1577.121 & 0.04 & 0.400 & 0.0485 & 1.202 \\
$100-200$ & 1577.121 & 0.01 & 0.409 & 0.0575 & 0.353 \\
$50-100$ & 1577.121 & 0.01 & 0.414 & 0.0356 & 0.132 \\
$0-50$ & 1577.121 & 0.00 & 0.417 & 0.0256 & 0.021 \\
& \multicolumn{7}{c}{ Total erosion } & & & 13.910 \\
\hline
\end{tabular}

Source : Author's analysis 2020

The total land erosion in the Bondoyudo watershed is $13.91 \mathrm{~mm} /$ ton/ha/year. 


\section{F. Erosion Index Calculation (IE)}

The average soil thickness of the Bondoyudo watershed is $100-150 \mathrm{~cm}$. A tolerable erosion value is obtained of 8 tonnes/ha/year. The amount of the calculation of the erosion index value is $I E=\frac{13,91}{8}=1,739$. The value is included in the erosivity index class category of the high recovery class.

\subsection{Water System Analysis}

\subsubsection{Flow Regime Coefficient Analysis}

In this analysis, the 10 years discharge data from the East Java Provincial PUSDA Office at Umbul DAM is used. Flow regime coefficient calculations are presented in Table 6. Based on the calculations, the average Flow Regime Coefficient is 25.04, with is included in the low recovery rate category.

Table 6. Calculation of Flow Regime Coefficients

\begin{tabular}{|c|c|c|c|c|c|c|}
\hline \multirow[b]{2}{*}{ No. } & \multirow{2}{*}{ Year } & \multicolumn{2}{|c|}{ River Discharge } & \multirow[b]{2}{*}{ KRS } & \multirow[b]{2}{*}{ Score } & \multirow[b]{2}{*}{ Class } \\
\hline & & QMaks & QMin & & & \\
\hline 1 & 2008 & 114,510 & 6,384 & 17.94 & 0.5 & very low \\
\hline 2 & 2009 & 98,216 & 444 & 221.21 & 1.5 & very high \\
\hline 3 & 2010 & 153,210 & 445 & 344.29 & 1.5 & very high \\
\hline 4 & 2011 & 124,140 & 9,822 & 12.64 & 0.5 & very low \\
\hline 5 & 2012 & 108,541 & 6,651 & 16.32 & 0.5 & very low \\
\hline 6 & 2013 & 44,954 & 7,854 & 5.72 & 0.5 & very low \\
\hline 7 & 2014 & 139,160 & 1,261 & 110.36 & 1.5 & very high \\
\hline 8 & 2015 & 108,943 & 20 & $5,322.60$ & 1.5 & very high \\
\hline 9 & 2016 & 53,943 & 556 & 97.02 & 1.25 & high \\
\hline 10 & 2017 & 86,475 & 7,774 & 11.12 & 0.5 & Very low \\
\hline Average & & 103,209 & 4,121 & 25.04 & 0.75 & Low \\
\hline
\end{tabular}

Source: Author's analysis 2020

\subsubsection{Annual Flow Coefficient and Sediment Load Analysis}

The analysis of annual flow coefficient calculations is obtained from the calculation of rainfall data and river discharge at Umbul Dam. Based on the results of the analysis, the average annual flow coefficient value is 0.27 , with this value included in the low recovery rate category.

The amount of sediment load is obtained as follows:

$\mathrm{MS}=\mathrm{A} \times \mathrm{SDR}=13.91$ ton $/$ ha $/$ year $\times 15.15 \%=2.108$

Based on the above calculations, the average sediment load value is 2.108 . It is included in the very low recovery rate category. 


\subsubsection{Flood Criteria Analysis}

Flood event data in the Bondoyudo watershed is presented in Table 7. The average value of flood events is more than once in 1 year. These conditions are included in the very high recovery rate category.

Table 7. Data on the Number of Flood Events in the Bondoyudo Watershed

\begin{tabular}{cccc}
\hline No. & Watershed & Year & Flood incident \\
\hline 1 & Bondoyudo & 2016 & 2 \\
2 & Bondoyudo & 2017 & 3 \\
3 & Bondoyudo & 2018 & 2 \\
4 & Bondoyudo & 2019 & 1 \\
Average & 2 & & \\
\hline
\end{tabular}

Source : Department of Public Works and Water Resources of East Java Province

\subsubsection{Water Use Index Analysis}

Data on water needs and availability are obtained from the PUSDA Office of East Java Province it presented in Table 8.

Table 8. Water Balance of Bondoyudowathershed

\begin{tabular}{lllllllll}
\hline \multirow{2}{*}{ Watershed } & $\begin{array}{l}\text { Catchment } \\
\text { Area } \\
(\mathrm{km} 2)\end{array}$ & $\begin{array}{l}\text { Water } \\
\text { availability } \\
(\mathrm{m} 3 / \text { years })\end{array}$ & $\begin{array}{l}\text { Water Availability } \\
\text { Domestic } \\
\text { (m3/years) }\end{array}$ & $\begin{array}{l}\text { Industry } \\
(\mathrm{m} 3 / \text { years) }\end{array}$ & $\begin{array}{l}\text { pond } \\
\text { (m3/years) }\end{array}$ & $\begin{array}{l}\text { irrigation } \\
\text { (m3/years) }\end{array}$ & $\begin{array}{l}\text { total } \\
\text { (m3/years) }\end{array}$ & $\begin{array}{l}\text { Water } \\
\text { Balance } \\
(\mathrm{m} 3 / \text { years) }\end{array}$ \\
\hline Bondoyudo & 1345.2 & $743,206,755$ & $48,958,304$ & $18,813,536$ & $1,904,110$ & $685,737,225$ & $755,413,176$ & $12,206,420$ \\
Total & 1345.2 & $743,206,755$ & $48,958,304$ & $18,813,536$ & $1,904,110$ & $685,737,225$ & $755,413,176$ &
\end{tabular}

Source : Department of Public Works and Water Resources of East Java Province

The Water Use Index value is, Water Use index = water demand / water availability $=755,413,176.66 / 743,206,304.10=1.02$ Based on the above calculations, the water use index value is 1.02 . It is included in the very high recovery rate category.

\subsection{Socio-Economic Analysis}

\subsubsection{Population Pressure and Population Welfare Analysis}

The area of agricultural land in the Bondoyudo watershed is 44.041 ha (Lumajang Regency 31.044 ha [19], Jember Regency 10.697 [20], Probolinggo Regency 2.300 [21]) with the number of farmer families in the Bondoyudo watershed area of 103,334 households. The population pressure index for land is calculated as follow:

$\mathrm{PPA}=\mathrm{A} / \mathrm{P}=44,041 / 103,334=0.43$

Based on the above calculations, the population pressure index value for land is 0.43 . The value is included in the very low recovery rate category. The total number of poor 
Families were 43,403, and the number of families in the Bondoyudo watershed was 214,386.

The calculation of the level of population welfare is approached as follows: PWA $=43,403$ / $214,386 \times 100 \%=20.25 \%$

Based on the above calculations, the value of the welfare level of the population is $20.25 \%$. The value is included in the category of poor recovery rate.

\subsection{Building Investment Analysis}

Most of the Bondoyudo watershed areas are in Lumajang Regency. Based on the number of residents $(82,187$ people in 2019), this location is included in small cities with a population. The city in the Bondoyudo watershed is in the low recovery level category. Bondoyudo Watershed has 8 provincial and central management authority weirs located in Lumajang and Jember Regencies with an irrigation area of 23,357 ha and 3 reservoirs. It is estimated that the investment value of the building is more than 60 billion rupiahs. Thus, the classification analysis of water construction investment in the Bondoyudo watershed is a very high recovery rate.

\subsection{Space Utilization Analysis}

\subsubsection{Protected Area Analysis}

Based on satellite imagery maps and land use maps, the protected area in the Bondoyudo watershed consists of $11,681.2$ ha of national parks and 6,855.55 ha of protected forest. The area of vegetation coverage in protected areas is obtained based on satellite image data with an area of 12,605.12 ha. Based on calculations, the value of the protected area level is.

$P A A=\frac{12.605,12}{18.536,94} \times 100 \%=68 \%$.

The value is included in the very high recovery rate category.

\subsubsection{Cultivation Area Analysis}

The amount of elevation of the slope is obtained from the slope map data of the BondoyudoWatershed at the Public Works and SDA Office of East Java Province. The land area with a slope of $0-25 \%$ in the Bondoyudo watershed is $123,939.51 \mathrm{Ha}$ or $92.13 \%$, with this value included in the category of very bad recovery rate. 


\subsection{Evaluation of Watershed Carrying Capacity}

The weighted value of the DAS classification was obtained with a total score of 103.25. Following the classification Table 9 for the watershed's carrying capacity, Bondoyudo watershed has a value of $90<\mathrm{DDD}<110$, which is included in the medium category.

Table 9. Evaluation of Watershed Carrying Capacity

\begin{tabular}{|c|c|c|c|c|c|c|c|c|c|}
\hline \multirow[b]{2}{*}{ No } & \multirow{2}{*}{\multicolumn{2}{|c|}{ Criteria/Sub Criteria }} & \multirow{2}{*}{ Weight } & \multicolumn{3}{|c|}{ Calculation Criteria } & \multicolumn{3}{|c|}{ Value (Weight x Score) } \\
\hline & & & & Calc. & Class & Score & Existing & Lowest & Highest \\
\hline I & Land & (40) & & & & & & & \\
\hline a & Perccentage of Critical Land & & 20 & $3.32 \%$ & $\begin{array}{l}\text { Very } \\
\text { low }\end{array}$ & 0.5 & 10 & 10 & 30 \\
\hline $\mathrm{b}$ & Percentage of Vegetation Cover & & 10 & $58 \%$ & Medium & 1 & 10 & 5 & 15 \\
\hline $\mathrm{c}$ & Erosion Index & & 10 & 1.74 & High & 1.25 & 12.5 & 5 & 15 \\
\hline II & Water System Analysis & (20) & & & & & & & \\
\hline a & Flow Regime Coefficient & & 5 & 25 & Low & 0.75 & 3.75 & 2.5 & 7.5 \\
\hline $\mathrm{b}$ & Annual Flow Coefficient & & 5 & 0.27 & Low & 0.75 & 3.75 & 2.5 & 7.5 \\
\hline $\mathrm{c}$ & Sediment Load & & 4 & 2.11 & $\begin{array}{l}\text { Very } \\
\text { low }\end{array}$ & 0.5 & 2 & 2 & 6 \\
\hline d & Flood & & 2 & & $\begin{array}{l}\text { Very } \\
\text { high }\end{array}$ & 1.5 & 3 & 1 & 3 \\
\hline $\mathrm{e}$ & Water Use Index & & 4 & 1.02 & $\begin{array}{l}\text { Very } \\
\text { high }\end{array}$ & 1.5 & 6 & 2 & 6 \\
\hline III & Social Economy Analysis & (20) & & & & & & & \\
\hline a & Populaton Pressure & & 10 & 0.43 & $\begin{array}{l}\text { Very } \\
\text { high }\end{array}$ & 1.5 & 15 & 5 & 15 \\
\hline $\mathrm{b}$ & Population Welfare & & 7 & 0.20 & $\mathrm{Bad}$ & 1.25 & 8.75 & 3.5 & 10.5 \\
\hline c & Existence of law and law enforcemen & & 3 & & Good & 0.75 & 2.25 & 1.5 & 4.5 \\
\hline IV & $\begin{array}{c}\text { Water Building Investment } \\
\text { Analysis }\end{array}$ & (10) & & & & & & & \\
\hline a & City Classification & & 5 & & Low & 0.75 & 3.75 & 2.5 & 7.5 \\
\hline $\mathrm{b}$ & Water Building Value Classification & & 5 & & $\begin{array}{l}\text { Very } \\
\text { high }\end{array}$ & 1.5 & 7.5 & 2.5 & 7.5 \\
\hline $\mathbf{V}$ & Space Utilization Analysis & (10) & & & & & & & \\
\hline & Protected Area Analysis & & 5 & 68 & $\begin{array}{l}\text { Very } \\
\text { bad }\end{array}$ & 1.5 & 7.5 & 2.5 & 7.5 \\
\hline & Cultivation Area & & 5 & 92.13 & $\begin{array}{l}\text { Very } \\
\text { bad }\end{array}$ & 1.5 & 7.5 & 2.5 & 7.5 \\
\hline & Total & & 100 & & & & 103.25 & 50 & 150 \\
\hline
\end{tabular}

Source: Author's analysis 2020

\subsection{Recommendation in Supporting Water Resources Development}

It is necessary to restore the criteria for the carrying capacity of the watershed that are lacking and maintain the criteria for the carrying capacity that are already good. To restore the watershed's carrying capacity, it must be integrated from upstream to downstream and involve interested parties or stakeholders. The priority of natural resources conservation activities is to maintain the sustainability of water resources' carrying capacity and function by conducting activities to protect and conserve water resources, water preservation, water quality management, and water pollution control [22]. The utilization of water resources is carried out following the spatial use directions in the river area by taking into account the water resources processing pattern. It aims to sustainably utilize 
Water resources by prioritizing the fulfillment of the community's basic needs fairly. It is possible to be done by stewardship of water resources, water resource provision, and wise use of water resources. Control of the destructive force of water is carried out comprehensively, including efforts to prevent, overcome, and restore the condition. Prevention effort is managed by planning to control the destructive force of water compiled in an integrated and comprehensive manner.

\section{Conclusion and Recommendation}

\subsection{Conclusion}

Based on the performance management of Bondoyudo Watershed in developing sustainable water resources, the result of the environmental sustainability score is 66 (medium category). This score is calculated based on land criteria, water management criteria, and space utility criteria. At the same time, the result of the social sustainability score is 37,5 (low category). This score is calculated based on social economy criteria and water building investment criteria. The total score of 103,25 indicates the medium category of Bondoyudo Watershed performance management. A higher than 100 means that watershed carrying capacity needs to be improved. Otherwise, the watershed will be degraded. Land criteria highly affect the performance of watershed carrying capacity. Thus, land criteria have to be prioritized for improvement. Water resources conservation, water resource utilization, and water damage control have to be wisely planned to restore watershed carrying capacity.

\subsection{Recommendation}

As an effort to conserve the Bondoyudo watershed in supporting the development of sustainable water resources, it is necessary to plan for integrated watershed restoration, starting upstream with reforestation and construction of check dams in tributaries, carrying out river restoration and organizing cultivation areas, and downstream with engineering rivers to prevent flooding. 


\section{References}

[1] J. Mosaffaie, A. Salehpour Jam, M. R. Tabatabaei, and M. R. Kousari, "Trend assessment of the watershed health based on DPSIR framework," Land use policy, vol. 100, no. October 2019, 2021, doi: 10.1016/j.landusepol.2020.104911.

[2] D. D. Himanshu S.K., Pandey A., "Assessment of Multiple Satellite-Based Precipitation Estimates Over Muneru Watershed of India. In: Pandey A., Mishra S., Kansal M., Singh R., Singh V. (eds) Water Management and Water Governance," Water Sci. Technol. Libr., vol. 96, no. Springer, Cham, 2021, doi: https://doi.org/10.1007/978-3-030-58051-3_5.

[3] M. Chadli, K., Boufala, "Assessment of water quality using Moroccan WQI and multivariate statistics in the Sebou watershed (Morocco)," Arab J Geosci 14, p. 27, 2021, doi: https://doi.org/10.1007/s12517-020-06296-5.

[4] J. L. P. Miranda A. Meehan, Peter L. O’Brien, Garret A. Hecker, "Integrating Rangeland Health and Stream Stability in Assessments of Rangeland Watersheds," Rangel. Ecol. Manag., vol. 75, no. ISSN 1550-7424, pp. 104-111, 2021, doi: https://doi.org/10.1016/j.rama.2020.12.005.

[5] R. Z. Abidin, M. S. Sulaiman, and N. Yusoff, "Erosion risk assessment: A case study of the Langat River bank in Malaysia," Int. Soil Water Conserv. Res., 2017, doi: 10.1016/j.iswcr.2017.01.002.

[6] Government of the Republic of Indonesia, Rules Minister of Forestry of the Republicof Indonesia Number: 52 / 2001, concerning Regarding the Guidelines for Implementation of Watershed Management. 2001.

[7] Government of the Republic of Indonesia, Rules Forestry Government of the Republic of Indonesia Number: P. 61 / Menhut-II / 2014 concerning Monitoring and Evaluation of Watershed Management, vol. 85, no. 1. 2014, pp. 2071-2079.

[8] S. Tukaram, N. PT, and G. MR, "Comparison of Area Reduction Method and Area Increment Method for Reservoir Sedimentation Distribution - Case Study Ujjani Dam,” Int. J. Res. Adv. Eng. Technol., 2016.

[9] A. C, Hydrology and Management Watershed. Yogyakarta: Gajah Mada University Press, 2010.

[10] S. Sarief, Soil and Water Conservation. Bandung: Pustaka Buana, 1985.

[11] S. I, Hydrology for Water Building Planing. Ban: Ide Darma, 1978. 
[12] R. Syaf, M. S. Hidayat, and E. Achmad, "Factors Affecting the Income of Poor Households Around the Bukit DuaBelas National Park (Case Study of TNBD Buffer Villages in MaroSeboUlu District, BatangHari Regency)," J. Perspekt. Financ. Develpment. Drh, 2013.

[13] Government of the Republic of Indonesia., Government Regulation No. 37 of 2014 concerning Soil and Water Conservation. 2014.

[14] I. Ikhsan, M. Fauzi, and S. Sutikno, "Analysis of the Investment Value of Buildings and Territorial Spatial Use for Watershed Supporting Capacity Assessments," J. Aptek, 2020, doi: 10.30606/aptek.v12i1.154.

[15] East Java Provincial Government, Regulations Region No. 188 / 391 / KPTS / 013/2013concerning Management Pattern of water resources in the Bondoyudo Bedadung River Basin. 2013.

[16] E. J. P. Department of Public Works for Water Resources, "The Draft of Bondoyudo Bedadung River Basin Management Plan Phase I Year 2015 and Phase II Year 2017,” 2017.

[17] Government of the Republic of Indonesia, Rules Forestry Government of the Republic of Indonesia Number: 09/ 2013, concerning Implementation procedures, Supporting Activities and Providing Incentives for Forest and Land Rehabilitation Activities, vol. 2007. 2013, pp. 1-19.

[18] H. C. Hardiyatmo, Land Slide and Erosion: Event and Handling. Yogyakarta, 2012.

[19] Central Bureau of Statistics, "Lumajang Regency in 2019 figures," 2019.

[20] Central Bureau of Statistics, Jember Regency in 2020 figures. 2020.

[21] Central Bureau of Statistics, Probolinggo Regency in 2020 figures. 2020.

[22] Government of the Republic of Indonesia, "Government Regulation No.23 of 1997 concerning Environmental Management," 1997. 